\title{
Fused mandibular incisors
}

INSERM

\section{Source}

INSERM. (1999). Orphanet: an online rare disease and orphan drug data base. Fused mandibular incisors. ORPHA:2287

Fused manidbular incisors is an extremely rare dental anomaly that is characterized by the union of two, normally separated, incisor tooth germs of the primary dentition. It is frequently associated with hypodontia (see this term) and an increased risk of pulp exposure. 